\title{
Geoffrey of Monmouth and the English Past
}

\author{
Rebecca Thomas
}

Geoffrey does not grant much space to the English in the De gestis Britonum. In one respect, this is unsurprising: Geoffrey's history extends back to the origins of the Britons in Troy, spending a significant amount of time in pre-Roman Britain, and as such the English enter the narrative rather late in the day. Even after their arrival, however, the English do not appear in the way which we might expect. The traditional narrative of the development of the English kingdoms, pioneered by sources such as Bede's Ecclesiastical History and the Anglo-Saxon Chronicle, and accepted and reproduced by many of Geoffrey's contemporary Anglo-Norman historians, has no place in the $D G B$. With his strikingly different version of events, Geoffrey certainly cannot be accused of lacking originality in his treatment of English history. The way in which he approached this subject is highly significant not only for our understanding of his attitude toward the English, but also for the composition of the $D G B$ more generally.

There was no shortage of contemporary historians writing of the English past, such as Henry of Huntingdon, the first version of whose History of the English, with which Geoffrey was most likely familiar, was completed by 113 . Henry presents us with a conventional account of English history, drawing heavily on Bede and the Anglo-Saxon Chronicle. ${ }^{1}$ Hengist and Horsa arrive in Britain in 449, and after recounting their dealings with the Britons, Henry proceeds through the various other Saxon settlers of the $5^{\text {th }}$ and 6 th centuries. Battles between them and the Britons are often recorded, and it is only after noting the foundation of the kingdom of Wessex in 519 and the 17-year rule of King Cerdic that Henry inserts a brief account of King Arthur, drawn mainly

1 Diana Greenway notes that about 25 per cent of History of the English derives from Bede, about 40 per cent from the Anglo-Saxon Chronicle: Henry of Huntingdon, History of the English, ed. and trans. D. Greenway, Henry, Archdeacon of Huntingdon: Historia Anglorum. The History of the English People, Oxford, 1996, p. lxxxv. Greenway also discusses the relationship between History of the English and De gestis Britonum, see pp. ci-ii, civ and 24, n. 35 . On Henry's presentation of the English past, see J. Campbell, "Some Twelfth-Century Views of the Anglo-Saxon Past", Peritia 3 (1984), 131-5o, at pp. 134-35 (repr. in id. (ed.), Essays in Anglo-Saxon History, London, 1986, 209-28). On the question of Geoffrey's familiarity with Henry's work, see also Tatlock, $L H B$, pp. 5 and 34 . 
from the 9th-century Historia Brittonum. ${ }^{2}$ After Arthur we return to a narration of the establishment of the various English kingdoms and their relations with each other in the 6th century. Henry dedicates a book to the conversion of the English, drawing heavily on Bede to recount Augustine's mission and the activities of the Christian kings of 7 th-century Northumbria. Moving beyond Bede, his narrative continues to track the fate and fortune of English kings and their kingdoms down to the Norman Conquest.

Henry's more conservative narrative helps us see just how different and inventive Geoffrey's history is. Where Henry tracks the development of the English kingdoms, Geoffrey relates a period of British supremacy. The $D G B$ transitions from the arrival of Hengist and Horsa to the dominance of the British kings Aurelius Ambrosius, Uther Pendragon, and Arthur. Arthur is followed by a series of British kings (drawn from Gildas's The Ruin of Britain) who are all successful in subduing the Saxon threat, until Kareticus, weakened by civil war, is defeated by an African army in alliance with the Saxons. It is only at this point that the Saxons gain the largest part of the island, which Geoffrey calls Loegria, and the Britons retreat to Cornwall and Wales. Geoffrey then relates the conversion of the English by Augustine before proceeding with an account of the $7_{\text {th }}$ century, which is, once more, largely a period of supremacy for the Britons. The British king Cadwallon controls all territory south of the Humber, a dominance which is only brought to an end when a plague forces his son and successor, Cadwaladr, to flee the island. The plague, Geoffrey stresses, also brings the Saxons to their knees, but once it passes, the survivors send word to their homeland, and a second migration results in the establishment of their supremacy over the island. Geoffrey ends by naming Æthelstan (893/4-939) as the first Saxon king to rule Loegria.

Where, then, are the English in the $D G B$ ? When is England? The period from the arrival of Hengist and Horsa in the $5^{\text {th }}$ century to the conversion of Northumbria and the successes of its kings in the 7th century is rewritten as a period of British dominance. The establishment of the English kingdoms painstakingly related in Henry's History of the English has no place in Geoffrey's work. While English kings and kingdoms do feature in Geoffrey's account of the 7th century, their success is halted by the military might of Cadwallon: the Northumbrian and Mercian kings are subsidiary characters, rulers only with his blessing. Indeed, in this section of the $D G B$, Northumbria and Mercia aside, Kent is the only other English kingdom to be mentioned, and this purely in the context of Augustine's mission. Indeed, there is no need to refer to any other kingdom: all territories south of the Humber are allegedly

2 Henry of Huntingdon, History of the English ii.18, ed. and trans. Greenway, pp. 98-101. 
under British overlordship. The period from the 7 th century onwards is simply absent, summarized in the statement that Æthelstan was the first to rule Loegria. Geoffrey's account of English history thus effectively jumps from the $7_{\text {th }}$ century to the 1oth.

This is more than simply a tongue-in-cheek re-writing of a traditional narrative. R. William Leckie, Jr. has illustrated how, through his re-casting of events, Geoffrey succeeds in postponing the passage of dominance over the island of Britain from the Britons to the Saxons. ${ }^{3}$ Thus, while Hengist and Horsa are undoubtedly important figures in the narrative, their arrival in 449 does not mark the beginnings of a gradually increasing English supremacy. With tales of Arthur and his successors, Britain, in Geoffrey's narrative, does still very much belong to the Britons. It is only after the death of Cadwaladr in the late 7 th century that dominance begins to pass to the English, a process completed, according to Geoffrey, by Æthelstan's reign in the 1oth century. ${ }^{4}$ The $D G B$ thus offers a dramatic alternative to the traditional narrative of the history of early medieval Britain.

What purpose Geoffrey harbored in constructing this alternative vision of British history is a contentious issue. It has been suggested that the $D G B$ served as a legitimization of Norman power in Britain and was perhaps intended to warn the Anglo-Normans of Geoffrey's day of the dangers of disunity. ${ }^{5}$ Conversely, Geoffrey has been labelled pro-British in his sympathies. Thus, John Gillingham has argued that the $D G B$ sought to combat the view, commonplace in the works of Anglo-Norman historians such as Henry of Huntingdon and William of Malmesbury, that the Britons were barbarians, and links this agenda to the political significance of the Welsh in the 103os, which was heightened by the rebellion of ${ }^{1136-38}$ and the subsequent alliance with Robert of Gloucester. ${ }^{6}$ As will be discussed further in this chapter, Geoffrey can certainly be charged with constructing a narrative of the English past that is more favorable to the Britons than the accounts found in any of his sources or in the work of his contemporaries. However, the complexity of the connection between

3 R.W. Leckie, Jr., The Passage of Dominion: Geoffrey of Monmouth and the Periodization of Insular History in the Twelfth Century, Toronto, 1981.

4 Leckie, Passage of Dominion, pp. 59-71.

5 F. Ingledew, "The Book of Troy and the Genealogical Construction of History: The Case of Geoffrey of Monmouth's Historia regum Britanniae", Speculum 69:3 (1994), 665-704, at pp. 681-88; P. Dalton, "The Topical Concerns of Geoffrey of Monmouth's Historia Regum Britannie: History, Prophecy, Peacemaking, and English Identity in the Twelfth Century", Journal of British Studies 44:4 (2005), 688-712; Leckie, Passage of Dominion, p. 57.

6 J. Gillingham, "The Context and Purposes of Geoffrey of Monmouth's History of the Kings of Britain", Anglo-Norman Studies 13 (1990), 99-118 (repr. in id. (ed.), The English in the Twelfth Century: Imperialism, National Identity and Political Values, Woodbridge, 2000, 19-39). 
Geoffrey's historical Britons and the Welsh of his own day makes it difficult to link this attitude to a clear political agenda. The Welsh may be the descendants of the historical Britons, but, according to Geoffrey, they are degenerati, "unworthy successors", who have lost both their name and their claim to the whole of Britain through civil strife. ${ }^{7}$ Consequently, that Geoffrey's narrative favors the Britons at certain points does not necessarily translate to support for the contemporary Welsh.

As Monika Otter has noted, that evidence can be found in the $D G B$ to support such a wide range of potential motivations "is surely indicative of a purpose beyond simply taking sides in contemporary political struggles". ${ }^{8}$ While not dismissing the indications that Geoffrey does, on occasion, show sympathy toward the Britons, Otter argues that, ultimately, the text ought to be understood as a parody in that it takes the same form as other medieval histories, but provides new content which conflicts with these previous works. ${ }^{9}$ The referentiality that governs the writing of William of Malmesbury and Henry of Huntingdon, namely, the grounding of their histories in perceived historical reality which is accessed through the works of earlier writers, does not concern Geoffrey. Thus, under the cover of following his alleged source material (Britannici sermonis librum uetustissimum, "a very old book in the British tongue"), he produces an original and inventive narrative of English history. ${ }^{10}$

This does not, however, mean that Geoffrey simply ignores all other accounts of English history. What is striking about the $D G B$ is that, while producing a dramatically different version of events, Geoffrey is nonetheless in constant dialogue with works such as Bede's Ecclesiastical History. It is clear from the broad outline of the work sketched above that Geoffrey does diverge from his sources in key respects. However, this issue requires assessment in

$D G B, x i .207 .598$. For a more detailed discussion of the relationship between the Welsh, Cornish, and Bretons and Geoffrey's historical Britons, see Ben Guy's contribution in this volume.

M. Otter, "Functions of Fiction in Historical Writing", in N. Partner (ed.), Writing Medieval History, London, 2005, pp. 109-30, at p. 120.

9 Otter, "Functions of Fiction", pp. 119-20; ead., Inventiones: Fiction and Referentiality in Twelfth-Century English Historical Writing, Chapel Hill, 1996, pp. 79-8o. See also V.I.J. Flint, "The Historia Regum Britanniae of Geoffrey of Monmouth: Parody and Its Purpose. A Suggestion", Speculum 54:3 (1979), 447-68. ship between history, truth, and fiction in the 12th century, see M. Kempshall, Rhetoric and the Writing of History, 400-1500, Manchester, 2011, esp. pp. 428-41, and in the context of Geoffrey of Monmouth specifically, see R.M. Stein, Reality Fictions: Romance, History, and Governmental Authority, 1025-1180, Notre Dame, 2006, pp. 106-25. 
a more specific context. To this end, the following examination will focus on two key parts of Geoffrey's narrative: the coming of the Saxons in 449 and the relations between the Britons and the kingdoms of Northumbria and Mercia in the 7 th century. I will consider what sources Geoffrey was using, and how he adapted these sources to depict the English in a certain way. I have thus far focused on Geoffrey's treatment of the English in the $D G B$, but there is something also to be said about their appearance in the $V M$. Here, Merlin prophesies the overthrow of the Britons by the Saxons until they are driven back by an alliance of Scots, Welsh, Cornish and Bretons. ${ }^{11}$ This prophecy, which is heavily reliant on the Welsh prophetic poem Armes Prydein Vawr ("The Great Prophecy of Britain"), is considered elsewhere in this volume, and consequently discussion of the $V M$ in this chapter will focus on Merlin's account of the interaction between the Britons and Saxons in the time of Vortigern. ${ }^{12}$ While the presentation of the English in the $D G B$ is the main avenue of investigation here, their treatment in the $V M$ will be considered where relevant.

The term "Anglo-Saxons" is conventionally associated with the period of increasing ties between the kingdoms of Mercia and Wessex in the 9th century and thereafter. ${ }^{13}$ Asser, in his Life of King Alfred, for example, refers to King Alfred as Anglorum Saxonum rex, "king of the Anglo-Saxons", and the term is frequently employed in charters of the 1oth century. ${ }^{14}$ In modern scholarship it is frequently used as a term to describe the English peoples before the Norman Conquest. It is not, however, a term used in Geoffrey's work. For his account of the 7 th century he does occasionally employ the term Angli, "English". Scholars have noted that this usage is confined to the period after Augustine's mission, and consequently may reflect the increasing influence of Bede's Ecclesiastical History on Geoffrey's work. ${ }^{15}$ However, for the most part, Geoffrey refers to the kings and peoples of specific kingdoms, for example, Mercii, "the Mercians", and Northamhimbri, "the Northumbrians". For the period prior to Augustine's mission, Geoffrey consistently uses Saxones, "the Saxons". Thus in the following discussion I will either refer to specific kingdoms, or will follow Geoffrey in referring to the Saxons.

\footnotetext{
$11 V M$, ll. 959-75. Cf. $D G B$, Prophetiae 115.110-16.

12 See Ben Guy's contribution to this volume.

13 For a summary of the evidence see S. Keynes, "Anglo-Saxons, Kingdom of the", in M. Lapidge, J. Blair, S. Keynes and D. Scragg (eds.), The Blackwell Encyclopaedia of Anglo-Saxon England, 2nd ed., Chichester, 2014, p. 40.

14 Asser, Life of King Alfred, ed. W.H. Stevenson, Asser's Life of King Alfred. Together with the Annals of Saint Neots, Oxford, 1959, p. 1, Dedication.

15 N. Wright, "Geoffrey of Monmouth and Bede", $A L 6$ (1986), 27-59, at p. 34; Tatlock, $L H B$, p. 19.
} 
Our first surviving source to recount the coming of the Saxons to Britain is Gildas's The Ruin of Britain, a text with which Geoffrey was certainly familiar. ${ }^{16}$ Geoffrey makes particular use of Gildas's complaint against the five tyrant kings to create a succession of British monarchs to succeed Arthur. ${ }^{17}$ Neil Wright has illustrated Geoffrey's practice of borrowing passages from Gildas's account of the coming of the Saxons and placing them elsewhere in his narrative - to fashion his account of the defeat of the British king Ceredig, for example. ${ }^{18}$ For the adventus Saxonum itself, however, there were other sources to which Geoffrey could turn, sources which, while themselves drawing on The Ruin of Britain, had developed Gildas's work. Most prominent among these sources were Bede's Ecclesiastical History and the Historia Brittonum (attributed to "Nennius" in certain manuscripts). ${ }^{19}$

Finishing his Ecclesiastical History in 731, Bede related the coming of the Saxons in greater detail than Gildas, bringing the deal struck between Hengist and Horsa and the superbo tyranno, "proud tyrant", whom he named Vortigern, to the fore. Developing Gildas's criticism of the Britons, Bede stressed how they had brought the disaster upon themselves. ${ }^{20}$ In 829 or 830 his narrative found a challenge in the form of Historia Brittonum. ${ }^{21}$ This history of the Britons is often viewed by scholars as a reply to Bede, mainly because the author stresses that,

16 The Ruin of Britain is conventionally dated to the first half of the 6th century, see T.M. Charles-Edwards, Wales and the Britons, 350-1064, Oxford, 2013, pp. 215-18; D.N. Dumville, "The Chronology of De Excidio Britanniae, Book I", in M. Lapidge and D.N. Dumville (eds.), Gildas: New Approaches, Woodbridge, 1984, pp. 61-84. Cf. N.J. Higham, The English Conquest: Gildas and Britain in the Fifth Century, Manchester, 1994, pp. 118-41.

17 Geoffrey records the five kings as succeeding one another, in contrast to Gildas's narrative, where the five kings are presented as contemporaries. See $D G B$, xi.179-86. Cf. Gildas, The Ruin of Britain $\S \S 28-36$, ed. and trans. M. Winterbottom, Gildas: The Ruin of Britain and Other Works (Arthurian Period Sources, 7), Chichester, 1978, pp. 29-36 and 100-05. For discussion of the impact of this alteration on Geoffrey's narrative, see Leckie, Passage of Dominion, p. 63.

18 N. Wright, "Geoffrey of Monmouth and Gildas", $A L 2$ (1982), 1-40, at pp. 11-12.

19 For discussion of Historia Brittonum's authorship see D.N. Dumville, "Nennius' and the Historia Brittonum", Studia Celtica 10/11 (1975-76), 78-95; P.J.C. Field, "Nennius and his History", Studia Celtica 30 (1996), 159-65; B. Guy, "The Origins of the Compilation of Welsh Historical Texts in Harley 3859", Studia Celtica 49 (2015), 21-56, at pp. 44-51.

20 Bede, Ecclesiastical History i.15, ed. and trans. B. Colgrave and R.A.B. Mynors, Bede's Ecclesiastical History of the English People, Oxford, 1969, pp. 48-53. Cf. Gildas, The Ruin of Britain $\S_{23}$, ed. and trans. Winterbottom, pp. 26 and 97.

21 For discussion of the date see D.N. Dumville, "Some Aspects of the Chronology of the Historia Brittonum", ввсs 25 (1972-74), 246-51. 
contrary to Bede's contention, the Britons played a key role in the conversion of the English. ${ }^{22}$ Geoffrey was certainly familiar with Historia Brittonum: he drew heavily upon the work for various episodes scattered throughout the $D G B$. While a thorough assessment of Geoffrey's familiarity with Historia Brittonum is conducted elsewhere in this volume, it is important in this context to think about the impact upon his presentation of the English. ${ }^{23}$ Crucially, in its version of the adventus Saxonum, Historia Brittonum heaps further detail on to the brief account provided by Bede, and also diverges from the Ecclesiastical History at several key points.

It is immediately clear that Geoffrey favored Historia Brittonum's account, and that, as Edmond Faral noted, it was his principal source for this section of the $D G B .{ }^{24}$ While there are instances where material is shared between all three texts, Geoffrey overwhelmingly draws on the narrative provided by Historia Brittonum. We have roughly the same events in both texts: Hengist gaining the friendship of Vortigern and gradually summoning a greater number of Saxons to Britain; Vortigern falling in love with Hengist's daughter; the battles of his son Vortimer against the Saxons; and the treachery of the long knives. ${ }^{25}$ As Historia Brittonum's narrative is longer and more detailed than that offered by Bede it is perhaps unsurprising that this was Geoffrey's chosen source. However, it is not simply Historia Brittonum's pattern of events which Geoffrey borrows: he also keeps the text's attitude toward the Britons and Saxons and its presentation of their role in these events.

We see an example of this immediately as Geoffrey follows Historia Brittonum in claiming that the Saxons arrived in Britain as exiles. This is in direct contrast to the narrative provided by Gildas, Bede, and the Anglo-Saxon Chronicle, and followed by Henry of Huntingdon and to an extent William of Malmesbury (as discussed below), who claim that the Saxons were invited to Britain. Bede adds that this occurred in 449 , and Gildas's superbo tyranno, "proud tyrant", is named Vortigern:

In the year of the Lord 449 Marcian, forty-sixth from Augustus, became emperor with Valentinian and ruled for seven years. At that time the race

22 See below for further discussion of the relationship between Historia Brittonum and Bede, p. 120 .

23 See Ben Guy's contribution to this volume.

24 Faral, $L L A$, vol. 3, pp. 215-16. Robert Hanning has highlighted the influence of Historia Brittonum on Geoffrey's work more generally; see R. Hanning, The Vision of History: From Gildas to Geoffrey of Monmouth, New York, 1966, pp. 138-39.

25 A more detailed breakdown of the episodes Geoffrey draws from Historia Brittonum can be found in Faral, $L L A$, vol. 3, pp. 215-17. 
of the Angles or Saxons, invited by the aforementioned king [Vortigern], came to Britain in three warships and by his command were granted a place of settlement in the eastern part of the island, ostensibly to fight on behalf of the country, but their real intention was to conquer it. ${ }^{26}$

While in Historia Brittonum Vortigern does later reach an agreement with the Saxons, to begin with they are simply exiles. This is crucial as it changes the role of the Britons in the episode, and the author's attitude toward them: both Gildas and Bede place the blame for the Saxon incursions firmly on the shoulders of the Britons, with Gildas specifically noting the stupidity of the Britons for inviting the Saxons when they already feared them. ${ }^{27}$ In Historia Brittonum's account this condemnation vanishes, and the Britons are rather presented as offering the hand of friendship to the Saxons who have nowhere else to go.

Using Historia Brittonum as a basis, Geoffrey embellishes this account to explain the reason for the exile of the Saxons: their land was overpopulated and thus Hengist and Horsa were forced to leave to make their fortune elsewhere. This account was in fact taken from William of Malmesbury, who, in his Deeds of the English Kings, offered this as an explanation not only for the incursion of the Saxons in Britain, but also the Vandals in Africa, the Goths in Spain, the Lombards in Italy, and the Normans in Gaul. ${ }^{28}$ Robert Hanning argued that by describing the Saxons as exiles, and by providing this detailed explanation of their fate, Geoffrey underlines the importance of their migration: they are not mere adventurers, but settlement founders. He notes the similarity to the Britons, who, in both Historia Brittonum and the $D G B$, had arrived in Britain as

26 Bede, Ecclesiastical History i.15, ed. and trans. Colgrave and Mynors, pp. 48-51: "Anno ab incarnatione Domini ccccxlviiii Marcianus cum Ualentiniano quadragesimus sextus ab Augusto regnum adeptus vii annis tenuit. Tunc Anglorum siue Saxonum gens, inuitato a rege praefato, Brittaniam tribus longis nauibus aduehitur et in orientali parte insulae iubente eodem rege locum manendi, quasi pro patria pugnatura, re autem uera hanc expugnatura suscepit." Cf. Gildas, The Ruin of Britain §23, ed. and trans. Winterbottom, pp. 26 and 97; ASC E 449, The Anglo-Saxon Chronicle: a Collaborative Edition. Vol. 7: MS. E, ed. S. Irvine, Cambridge, 2004, p. 16; Henry of Huntingdon, History of the English ii.1, ed. and trans. Greenway, pp. 78-79; William of Malmesbury, Deeds of the English Kings, ed. and trans. R.A.B. Mynors, completed by R.M. Thomson and M. Winterbottom, William of Malmesbury: Gesta Regum Anglorum, The History of the English Kings, 2 vols., Oxford, 1998-99, vol. 1, pp. 20-21.

27 Gildas, The Ruin of Britain §23, ed. and trans. Winterbottom, pp. 26 and 97.

28 William of Malmesbury, Deeds of the English Kings i.5.1-3, ed. and trans. Mynors, vol. 1, pp. 22-23. For further discussion of William's account, and his sources, see Faral, $L L A$, vol. 3, pp. 218-19. 
exiles from Troy. ${ }^{29}$ However, as noted above, the importance of the migration of 449 is diminished in Geoffrey's work. Indeed, a further migration, after the plague of the 7 th century, is required before the Saxons are able to gain dominance over the island. ${ }^{30}$ Consequently, it is perhaps of greater significance here that Geoffrey follows Historia Brittonum in rejecting the notion that the Saxons were invited by the Britons, thus relieving the Britons of any blame for their initial arrival. This is particularly significant considering that William of Malmesbury, who is, after all, Geoffrey's source for this explanation of the Saxons' exile, also includes the claim made by Gildas and Bede that the Saxons were invited to Britain. In William of Malmesbury's account, the Saxons are invited exiles, while in the $D G B$ they are simply exiles.

Geoffrey also follows Historia Brittonum in stressing the paganism of the Saxons. As an introduction to the Saxons when they arrive in Britain, Historia Brittonum explains that they were descended from Geta, an idol they used to worship as God. ${ }^{31}$ While Bede and the Anglo-Saxon Chronicle recorded the genealogy of the Saxons as far back as Woden, these texts simply listed the names of the ancestors without further comment. ${ }^{32}$ Geoffrey not only follows Historia Brittonum here, but also develops its account: in the $D G B$, Vortigern immediately notes that he is saddened by the incredulitas, "faithlessness", of the Saxons. ${ }^{33}$ While Vortigern, despite this initial query, does not view their paganism as a barrier to the forming of an alliance, it is clear that the rest of the Britons are uncomfortable. Thus, later in Geoffrey's narrative, the Britons ask Vortigern to expel the Saxons from the island, as they are worried about the extent to which the Christian Britons are intermingling with the pagan Saxons. ${ }^{34}$ This is particularly interesting in light of what Henry of Huntingdon has to say on the matter. He also stresses the paganism of the Saxons (and reproduces Historia Brittonum's account of Geta), yet he focuses on how, in seeking help from the pagan Saxons, the Britons turned their backs on God and were justly punished as a consequence. ${ }^{35}$ In Geoffrey's narrative, not only do the Britons not invite the Saxons, but they are also uncomfortable with their paganism.

29 Hanning, Vision of History, p. 170.

$30 \quad$ Leckie, Passage of Dominion, pp. 59-71. See discussion above, p. 107.

$31 \quad$ Historia Brittonum (Harley 3859) §31, ed. Faral, LLA, vol. 3, pp. 2-62, at p. 23.

32 Bede, Ecclesiastical History i.15, ed. and trans. Colgrave and Mynors, pp. 50-51; ASC E 449, ed. Irvine, p. 16.

$33 D G B$, vi.98.285-86.

$34 \quad D G B$, vi.101.391-96.

35 Henry of Huntingdon, History of the English ii.1, ed. and trans. Greenway, pp. 78-79. For discussion of how Henry presents five invasions of the island of Britain (Romans, Picts and Scots, Saxons, Vikings, and Normans) as five punishments from God, see Henry of Huntingdon, History of the English, ed. and trans. Greenway, p. lix; A. Galloway, "Writing 
The role of Vortigern here also merits comment. It is notable that Vortigern accepts the paganism of the Saxons, while the rest of the Britons protest. Of course, this focus on the actions of specific individuals is a key characteristic of Geoffrey's work, and has been viewed as part of a wider trend in Anglo-Norman historical writing. ${ }^{36}$ Thus the history revolves around the actions of individuals such as Brutus, Arthur, Vortigern, and Cadwallon. However, it is nonetheless significant that the Britons as a group are uncomfortable with Vortigern's acceptance of the Saxons. According to Hanning, this illustrates the "separation of individual and nation"; the Britons are not to blame for Vortigern's crimes. ${ }^{37}$ This is a pattern which we can already see in Historia Brittonum, where every decision made concerning the Saxons is presented as being Vortigern's alone, thus minimizing the responsibility of the Britons as a collective for the ensuing disasters. It is Vortigern who receives the Saxons and grants them Thanet, and Vortigern who falls in love with Hengist's daughter and grants him the kingdom of Kent. ${ }^{38}$ While reproducing this focus on Vortigern fits Geoffrey's wider preoccupation with the actions of specific individuals, it nonetheless also gives the impression that it is Vortigern alone who is mainly to blame for the successes of the Saxons. Geoffrey's claim that the rest of the Britons were dissatisfied with Vortigern's actions accentuates this impression.

Hanning argued that a further illustration of this disconnect between Vortigern and the people he claimed to rule was Geoffrey's retelling of the treachery of the long knives. ${ }^{39}$ In Historia Brittonum, 300 unarmed British elders (seniores) are slaughtered by the Saxons at the peace conference, and Vortigern is the only Briton left alive. ${ }^{40}$ William of Malmesbury develops this narrative. In his account, the Britons are invited to a feast, and no mention is made of them being unarmed. Hengist goads them into a fight and all are slaughtered. ${ }^{41}$ Geoffrey, in contrast to both these accounts, focuses on the resistance and bravery of the Britons: despite being unarmed, they fight bravely and cause significant damage to the Saxons. He relates how Eldol, earl of Gloucester, wards off the Saxons with a staff and eventually manages to

History in England", in D. Wallace (ed.), The Cambridge History of Medieval English Literature, Cambridge, 1999, pp. 255-83, at pp. 263-64.

36 Hanning, Vision of History, esp. pp. 124-44.

37 Hanning, Vision of History, p. 151.

38 Historia Brittonum $\S 31$ and 37 , ed. Faral, $L L A$, vol. 3, pp. 23 and 27-29.

39 Hanning, Vision of History, pp. 151-52. Faral also points to this episode as an example of Geoffrey attempting to present the Britons in a more positive light, see Faral, $L L A$, vol. 2, pp. 228-29.

$40 \quad$ Historia Brittonum §46, ed. Faral, $L L A$, vol. 3, p. 34 .

41 William of Malmesbury, Deeds of the English Kings i.8.3, ed. and trans. Mynors, vol. 1, pp. $26-27$. 
escape. ${ }^{42}$ These additions present the Britons as playing a far more active role in the treachery of the long knives, and the victory of the Saxons as less swift and straightforward than in Historia Brittonum's account. On the side of the Saxons, their treachery is lifted wholesale from Historia Brittonum. As well as the treachery of the long knives, Geoffrey reproduces Historia Brittonum's account of Hengist's scheme to marry his daughter to Vortigern. Indeed, Geoffrey quotes Historia Brittonum's description of Hengist as a uir doctus atque astutus, "a shrewd and cunning man", and copies Hengist's speech to Vortigern claiming his right, as his father-in-law, to advise him in all matters. ${ }^{43}$

In relating the coming of the Saxons and their initial settlement in the island of Britain, it is clear that Geoffrey is primarily reliant upon Historia Brittonum. To a certain degree this is unsurprising as, of the surviving sources, it is Historia Brittonum that provides the most detailed account of these events. However, Geoffrey is also making a deliberate choice: he follows Historia Brittonum over Gildas, Bede, and the Anglo-Saxon Chronicle in presenting the Saxons as exiles, for example. In choosing Historia Brittonum's narrative over Bede's, which was, as we have seen, favored by his contemporaries William of Malmesbury and Henry of Huntingdon, Geoffrey sides, in this instance, with the account which is most favorable to the Britons. Nor is he content to simply reproduce Historia Brittonum's depiction: he loads the skeletal narrative provided by his source with additional material; but this material accentuates, rather than contradicts, the attitude already present in Historia Brittonum. Geoffrey's additions thus stress and develop the negative characteristics of the Saxons, while increasing the agency of the Britons and presenting a sympathetic view of their dealings with Hengist and his followers.

This is not to say that Geoffrey presents a consistently favorable view of the Britons. Influenced by Gildas, he dwells on the destructive tendency of the Britons toward civil war, as in the $P M$, where Merlin prophesies that "then the red dragon will return to its old ways and strive to tear at itself." 44 Indeed, the different presentation of the adventus Saxonum in the VM illustrates the ambiguity and complexity of Geoffrey's motivations. The Saxons are still presented as treacherous and deceitful, doing damage to Britain through their prodicione nefanda "black treachery" and killing the Britons at a peace conference premeditate fraude, "by calculated deceit", but the agency granted to the

\footnotetext{
$42 \quad D G B$, vi.104-O5.

43 Historia Brittonum $\S 37$ and 38, ed. Faral, $L L A$, vol. 3, pp. 27 and 29. Cf. $D G B$, vi.99.301-O2 and vi.101.378-83.

$44 D G B$, Prophetiae, 113.56-57: "Exin in proprios mores reuertetur rubeus draco et in se ipsum saeuire laborabit." Cf. Gildas, The Ruin of Britain $\S \S 26-27$, ed. and trans. Winterbottom, pp. $28-29$ and $98-99$.
} 
Britons in the $D G B$ is absent. ${ }^{45}$ Nor are the Saxons described as exiles in the $V M$, with Merlin instead recounting how Vortigern, unable to withstand rebellion, called for the assistance of foreign warriors, an account closer to that provided by Gildas and Bede than to Historia Brittonum. Merlin continues: "Soon bands of fighting men arrived from all over the world and he welcomed them. In particular, the Saxons sailed in in curved ships and brought their helmeted troops to his service." 46 The actions of the Saxons and Vortigern's culpability take center stage in the VM's narrative, as illustrated by the way Merlin introduces the account with the statement "for I have lived long and seen much - our own folk turning on one another, and the chaos the barbarian brings." ${ }^{47}$ Thus the $V M$ offers a somewhat different perspective on the adventus Saxonum to that given in the $D G B$.

As noted above, Geoffrey uses the liber uetustissimus, "very ancient book", to provide $D G B$ with the appearance of textual authority, to suggest that, although his history diverges dramatically from the conventional narrative of English history seen in the works of Bede and his contemporary Anglo-Norman historians, it is nevertheless operating within a pre-existing framework. ${ }^{48}$ However, this did not entail a complete rejection of what had come before, as the influence of Historia Brittonum on the account of the adventus Saxonum in the $D G B$ illustrates. While the above consideration of the $V M$ warns against the view that Geoffrey had a straightforward overarching agenda to exonerate the Britons of the past, it remains that, in recounting the adventus Saxonum in the $D G B$, he follows the source most favorable to the Britons, and develops this material to create an account which is more sympathetic still.

\section{2 \\ A Narrative of British Domination}

As explained at the beginning of this chapter, in Geoffrey's narrative the adventus Saxonum is followed by an account of a series of British kings who wage war successfully against the Saxons, the most famous of these being King Arthur. What is a period of formation and consolidation of English kingdoms

\footnotetext{
$45 \quad V M, 11.1004$ and 1010-11.

$46 V M$, ll. 999-1002: "Mox ex diversis venerunt partibus orbis pugnaces turme, quas excipiebat honore. Saxona gens etiam curvis advecta carinis ejus ad obsequium galeato milite venit."

$47 V M$, ll. 979-81: "nam tempore multo vixi videns et de nostratibus in se et de barbarica turbanti singular gente."

48 Otter, "Functions of Fiction", p. 120.
} 
in the Anglo-Saxon Chronicle and Henry of Huntingdon's Historia Anglorum becomes a period of British domination in the $D G B$. In the present context it is how Geoffrey's narrative proceeds beyond the history of these kings that is significant, as it once more overlaps with familiar sources. In particular, his account of the conversion of the English in the 6th century, and the subsequent wars between the Britons, Mercians, and Northumbrians in the 7th century, bears signs of being influenced by Bede's Ecclesiastical History. This offers a good opportunity to examine how Geoffrey adapted his sources in his depiction of relations between the Britons and the Saxons.

This section of the $D G B$ covers Augustine's mission at the end of the 6th century and the reigns of three kings of the Britons: Cadfan (fl. c.616-c.625), Cadwallon (d. 634), and Cadwaladr (d. 664/682). Geoffrey tracks the passing of supremacy back and forth between these kings of Gwynedd and the Northumbrians. There are certain episodes in this narrative which are entirely unique to Geoffrey's work, for example, Cadwallon's flight to Brittany to seek the help of King Salomon and the mission of his nephew, Brianus, to kill Edwin's augur Pellitus, whose magic was preventing the Britons from returning to the island ${ }^{49}$ There are other episodes which, it has been suggested, may have some grounding in Welsh tradition, for example the claim made by Geoffrey that Edwin and Cadwallon were brought up together at the court of Cadfan of Gwynedd. ${ }^{50}$

However, for the most part, the basis of this section of Geoffrey's work is Bede's Ecclesiastical History. Geoffrey uses Bede's work as a skeleton to which he adds further material, much like his use of Historia Brittonum discussed above. However, while Geoffrey did not, on the whole, dramatically change the direction and message of Historia Brittonum, here he diverges wildly from his source. His treatment of Cadwallon serves as an introductory example of this trend. According to Bede, Cadwallon killed a succession of Northumbrian kings (Edwin, Osric, and Eanfrith), before he himself was defeated in battle and killed by Oswald at Heavenfield in $634 .{ }^{51}$ In Geoffrey's narrative, however,

$49 D G B$, xi.193-96. For discussion of the reasons behind such additions, see Faral, $L L A$, vol. 2, p. 329 .

$50 \quad$ N.K. Chadwick, "The Conversion of Northumbria: A Comparison of Sources", in ead. (ed.), Celt and Saxon: Studies in the Early British Border, Cambridge, 1963, pp. 138-66, at pp. 14951; Charles-Edwards, Wales and the Britons, p. 389, n. 52. Cf. V. Tudor, "Reginald's Life of Oswald", in C. Stancliffe and E. Cambridge (eds.), Oswald: Northumbrian King to European Saint, Stamford, CT, 1995, pp. 178-94, at pp. 182-83.

51 Bede, Ecclesiastical History ii.2O and iii.1, ed. and trans. Colgrave and Mynors, pp. 202-05 and 212-15. Historia Brittonum also records that Cadwallon was killed by Oswald, at the battle of Cantscaul; see $\S 64$, ed. Faral, $L L A$, vol. 3, p. 43 . 
Cadwallon was not present (and did not die) at Heavenfield. Rather the battle is fought between Oswald and Penda of Mercia. Though Oswald is victorious on this occasion he does not kill the Mercian king, and Penda subsequently kills him at Burne. In Bede's account, Penda does kill Oswald, but this happens some time after the defeat and death of Cadwallon, at the battle of Maserfelth (or Cocboi) in $642 . .^{52}$ Geoffrey's reference to "Burne" may be an appropriation of Bede's Denisesburn, the name given in the Ecclesiastical History for the battle of Heavenfield. The striking point that emerges from a brief comparison of these two narratives is that Geoffrey's Cadwallon remains alive and active for much longer than Bede's account allows. Indeed, in Geoffrey's narrative, Cadwallon remains overlord of the Britons, Mercians, and Northumbrians until his death from illness and old age, after reigning for 48 years..$^{53}$

Of course, as Faral explained, by simply rejecting the notion that Cadwallon and the Britons were ever fatally defeated by the Northumbrians, Geoffrey accords his subjects a far more favorable treatment than that given to them by Bede. ${ }^{54}$ In so doing he also naturally diminishes the achievement of the Northumbrians. Rather than dying at Oswald's behest, Cadwallon survives to preside over Oswald's death, the reign of his successor, Oswiu, and the death of Penda, king of the Mercians. As discussed briefly already, it has long been recognized that this extension of Cadwallon's life, and the consequent extension of British dominance, has the impact of delaying the final victory of the Saxons, and the passing of control of the island of Britain into their hands. Leckie draws attention in particular to Geoffrey's account of the agreement between Cadfan and Æthelfrith, whereby the Humber was set as the boundary between their territories. That Cadfan, like Cadwallon after him, is described as ruling the territories south of the Humber dismisses the significance of Saxon settlement in the south. Moreover, while Cadwallon is initially expelled from Britain by Edwin, his eventual victory and subsequent dominance over the Northumbrian kings underlines the weakness of the position of the Saxons north of the Humber. The implication is that the Britons remained a force to be reckoned with throughout the 7 th century, and indeed Geoffrey does not allow the Saxons to gain complete control of Loegria until the reign of Æthelstan in the 1oth century. 55

Crucially, this diminishing of the dominance of the Saxons is not restricted to the extension of Cadwallon's life and reign. Cadwallon is presented as a more

\footnotetext{
52 For discussion of the location of Oswald's death and the various place-names used see C. Stancliffe, "Where was Oswald killed?" in Stancliffe and Cambridge, Oswald, pp. 84-96. $D G B$, xi.201.504-12.

54 Faral, $L L A$, vol. 2, pp. 331-32.

55 Leckie, Passage of Dominion, esp. pp. 66-72.
} 
powerful overlord than Bede's Northumbrian kings, three of whom (Edwin, Oswald, and Oswiu) are included in his list of kings who managed to extend their rule over all the southern kingdoms. ${ }^{56} \mathrm{~A}$ brief examination of how Bede and Geoffrey present the affairs of Mercia after the death of Penda illustrates this point. After defeating Penda at Winwaed, Bede tells us that Oswiu gave the Mercian kingdom to the deceased king's son Peada. However, Peada was subsequently murdered, and three Mercian ealdormen, Immin, Eafa, and Eadberht, rebelled against Oswiu, choosing another of Penda's sons, Wulfhere, as king. ${ }^{57}$ Geoffrey, in contrast, presents Cadwallon as the constant force behind the development of events. With no mention of Peada, he presents Wulfred (Bede's Wulfhere) as succeeding to the kingdom of the Mercians, significantly with Cadwallon's blessing. While Wulfred subsequently allies himself with the Mercian leaders Eba and Edbert to rebel against Oswiu, Cadwallon orders them to make peace..$^{58}$ Geoffrey's Cadwallon thus has a far firmer grip on events in Mercia than Bede's Oswiu.

The extension of Cadwallon's life, and the consequent dramatic re-shaping of events, is an obvious divergence from Bede's narrative. However, Geoffrey's engagement with the version of the English past presented in the Ecclesiastical History is multi-layered and in many respects subtler than his treatment of Cadwallon might suggest. Geoffrey is in constant dialogue with Bede, and Neil Wright has produced a thorough survey, highlighting each instance of dependence, but also divergence..$^{59}$ I will not reproduce such a list here, but rather will focus on examining one example in detail, which will illustrate the complexity and sophistication of Geoffrey's response to the Ecclesiastical History.

\section{3}

\section{Conversion and Christian Kings}

Focusing in particular on issues of conversion and Christianity allows us to gain an insight into how Geoffrey reacts to this key plank of Bede's work. Much of this relates to his depiction of 7 th-century kings, but it is worth starting

56 Bede, Ecclesiastical History ii. 5, ed. and trans. Colgrave and Mynors, pp. 148-51. For further discussion, see P. Wormald, "Bede, the Bretwaldas and the Origin of the Gens Anglorum", in P. Wormald et al. (eds.), Ideal and Reality in Frankish and Anglo-Saxon Society, Oxford, 1983, pp. 99-129; Charles-Edwards, Wales and the Britons, pp. 426-27; S. Keynes, "Bretwalda or Brytenwalda", in Lapidge et al. (eds.), Blackwell Encyclopaedia of Anglo-Saxon England, pp. $76-77$.

57 Bede, Ecclesiastical History iii.24, ed. and trans. Colgrave and Mynors, pp. 294-95.

$5^{8} \quad D G B, \mathrm{xi} .200 .500-03$.

59 Wright, "Geoffrey of Monmouth and Bede". 
by moving back to 597 and the Augustinian mission. One of Bede's key complaints against the Britons is that they shunned the duty expected of them as Christians in refusing to assist in Augustine's mission to convert the Saxons. Bede relates how Augustine requested the Britons to do three things: keep Easter at the correct date, perform the sacrament of baptism, and preach to the Saxons. However, the Britons, believing Augustine to be proud as he had not risen from his seat at their approach, rejected these requests, refusing also to accept Augustine as archbishop over them. ${ }^{60}$ This appears to be the primary reason for Bede's negative treatment of the Britons in his Ecclesiastical History ${ }^{61}$ It proved to be a controversial view. As noted above, Historia Brittonum, composed a century or so after Bede finished his Ecclesiastical History, appears to present a case in defense of the Britons in claiming that Edwin of Northumbria was baptized by a Briton, Rhun ab Urien, and that Rhun continued to baptize omne genus ambronum, "the entire race of the Ambrones (sc. English)", for 40 days. ${ }^{62}$

Wright has argued that Geoffrey also answers this charge, but rather than following Historia Brittonum's lead and presenting an entirely different set of events, Geoffrey simply adapts Bede's tale of the meeting at Augustine's Oak to reflect positively upon the Britons. A key part of this adaptation involves careful attention to structure. ${ }^{63}$ Geoffrey notes Augustine's arrival in Britain, but then, unlike Bede, turns to provide a description of the ecclesiastical

6o Bede, Ecclesiastical History ii.2, ed. and trans. Colgrave and Mynors, pp. 134-41. While Bede refers to Augustine as archiepiscopus, his status was more correctly that of a metropolitan bishop, see T.M. Charles-Edwards, Early Christian Ireland, Cambridge, 2000, pp. 416-20.

61 For more extensive discussion of Bede's view of the Britons, see T.M. Charles-Edwards, "Bede, the Irish and the Britons", Celtica 15 (1983), 42-52; W.T. Foley and N. Higham, "Bede on the Britons", Early Medieval Europe 17 (2009), 154-85; A.T. Thacker, "Bede, the Britons and the Book of Samuel", in S. Baxter et al. (eds.), Early Medieval Studies in Memory of Patrick Wormald, Ashgate, 2009, pp. 129-47.

62 Historia Brittonum $\S 63$, ed. Faral, $L L A$, vol. 3, p. 43. Ambrones is normally interpreted as a nickname for the English, meaning "robbers", see D.N. Dumville, "The Textual History of the Welsh-Latin Historia Brittonum", 3 vols., unpublished PhD thesis, University of Edinburgh, 1975, vol. 1, p. 238, n. 3. It is possible that the author of Historia Brittonum came across the name in Gildas's The Ruin of Britain, where it is used to describe the Picts and the Irish, see Gildas, The Ruin of Britain §16, ed. and trans. Winterbottom, pp. 21 and 94. For scholarship suggesting that Historia Brittonum was replying to Bede see D.N. Dumville, "Historia Brittonum: An Insular History from the Carolingian Age", in A. Scharer and G. Scheibelreiter (eds.), Historiographie im frühen Mittelalter, Wien, 1994, pp. 406-34, at p. 434; N.J. Higham, "Historical Narrative as Cultural Politics: Rome, 'British-ness' and 'English-ness', in id. (ed.), The Britons in Anglo-Saxon England, Woodbridge, 2007, pp. 68-79, at p. 76; Charles-Edwards, Wales and the Britons, pp. 446-47.

63 Wright, "Geoffrey of Monmouth and Bede", pp. 35-36. 
organization of the British church, stressing the historic division of Britain into three archbishoprics (York, London, Caerleon) since the conversion of Lucius, king of the Britons, in the time of Pope Eleutherius. ${ }^{64}$ Not only does this stress the antiquity and continuity of the British church, but it also stresses the novelty of Augustine's position as archbishop of Canterbury. ${ }^{65}$ Further to this, Geoffrey focuses purely on Augustine's desire that the Britons submit to his authority, and preach to the Saxons, making no mention of the other two requests (regarding the dating of Easter, and baptism) recorded in Bede. As Augustine's speech outlining his demands is placed immediately following the detailed description of the organization of the British church, Geoffrey succeeds in depicting the request as somewhat unreasonable. Unreasonable, too, the request that the Britons assist in the mission when Geoffrey prefaces the meeting between the British bishops and Augustine with an account of how the Britons were ravaged by the Saxons. Indeed, Abbot Dinoot, spokesman for the Britons, replies to Augustine that the Britons could not possibly preach to a people who were depriving them of their country. ${ }^{66}$ Geoffrey continues, "and for that reason the British detested them, despising their faith and beliefs and shunning them like dogs." ${ }^{67}$ Wright has pointed out that this is in fact an adaptation of a statement made by Bede elsewhere in his Ecclesiastical History. ${ }^{6}$ After describing the suffering inflicted upon Northumbria by the Welsh and the Mercians, Bede claims that "indeed to this very day it is the habit of the Britons to despise the faith and religion of the English and not to co-operate with them in anything more than with the heathen." ${ }^{69}$ While this statement was formulated by Bede as an attack on the actions of the Britons, in Geoffrey's narrative these actions are made to seem perfectly legitimate.

Neil Wright's examination thus very clearly demonstrates how Geoffrey carefully re-ordered Bede's narrative, emphasizing different points and providing a very specific additional context, resulting in a more favorable depiction

64 This tradition is recorded in Historia Brittonum, and derives ultimately from the Book of the Popes (Liber Pontificalis). For discussion see Charles-Edwards, Wales and the Britons, pp. $322-23$.

65 Wright, "Geoffrey of Monmouth and Bede", p. 36.

66 Wright, "Geoffrey of Monmouth and Bede", pp. 37-38.

$67 \quad D G B$, xi.188-89.193-95: "unde eos summon habebant odio fidemque et religionem eorum pro nichilo habebant nec in aliquo Anglis magis quam canibus communicabant."

68 Wright, "Geoffrey of Monmouth and Bede", pp. 37-38.

69 Bede, Ecclesiastical History ii.20, ed. and trans. Colgrave and Mynors, pp. 204-o5: "quippe cum usque hodie moris sit Brettonum fidem religionemque Anglorum pro nihili habere, neque in aliquo eis magis communicare quam paganis." See also Henry of Huntingdon, History of the English iii.33, ed. and trans. Greenway, pp. 184-85. This passage in Bede's Ecclesiastical History is discussed in further detail below, see pp. 123-24. 
of the Britons. What this means in this case is a neutralization of Bede's description of the Britons as "bad" Christians. However, in this section I would like to illustrate that Geoffrey does not confine his efforts to defend the Britons against Bede's charges to his account of Augustine's meeting with the British bishops. Rather, his preoccupation with combating Bede's view of the Britons as "bad" Christians influences his presentation of the events of the 7 th century more generally, as exemplified by his treatment of the conflict between the Britons and Northumbrians.

Bede's Northumbrian rulers are all pious Christian kings who are harassed by the pagan Mercians. Edwin is the first Northumbrian king to be converted, Oswald is victorious at the battle of Heavenfield after raising a cross and beseeching his army to kneel and pray, and Oswiu's defeat of Penda paves the way for the conversion of the Mercians. While, as already noted, Geoffrey dramatically alters Bede's narrative concerning these kings by extending Cadwallon's life and dominance, it is worth looking more closely at the difference in the depiction of the events by the two authors. In Bede's account, the paganism of the Mercians is stressed. When describing the attacks on Northumbria in the aftermath of Edwin's death, Bede states, "Penda and the whole Mercian race were idolaters and ignorant of the name of Christ." ${ }^{\text {" }} \mathrm{He}$ proceeds to note that Oswald was killed by "the same heathen people and the same heathen Mercian king as Edwin".71 His successor, Oswiu, was attacked by the heathen people, the Mercians (pagana gente Merciorum, "the pagan Mercian people") who had killed his brother. ${ }^{72}$ Finally, Bede depicts Oswiu's defeat of Penda as Christian victory, which is followed by the conversion of the Mercians:

King Oswiu brought the campaign to a close in the district of Loidis (Leeds) on 15 November in the thirteenth year of his reign, to the great benefit of both peoples; for he freed his own subjects from the hostile devastations of the heathen people and converted the Mercians and the neighbouring kingdoms to a state of grace in the Christian faith, having destroyed their heathen ruler. ${ }^{73}$

$70 \quad$ Bede, Ecclesiastical History ii.2o, ed. and trans. Colgrave and Mynors, pp. 202-o3: "Penda cum omni Merciorum gente idolis deditus et Christiani erat nominis ignarus."

71 Bede, Ecclesiastical History iii.9, ed. and trans. Colgrave and Mynors, pp. 242-43: “... eadem pagana gente paganoque rege Merciorum".

72 Bede, Ecclesiastical History iii.14, ed. and trans. Colgrave and Mynors, pp. 254-55.

73 Bede, Ecclesiastical History iii.24, ed. and trans. Colgrave and Mynors, pp. 292-93: "Hoc autem bellum rex Osuiu in regione Loidis tertio decimo regni sui anno, septima decima die kalendarum Decembrium, cum magna utriusque populi utilitate confecit. Nam et suam gentem ab hostile paganorum depopulatione liberauit, et ipsam gentem 
Thus not only are the Mercians depicted as pagans, but this paganism is specifically associated with Penda. Moreover, Oswiu is presented as a glorious Christian king in facilitating the conversion of a heathen people. This is of course in contrast to the Britons, who are, according to Bede, a stubborn, proud people who refused to preach to the Saxons. Bede's description of Cadwallon and the Britons is illuminating in this context. Specifically, in the aftermath of Edwin's death at the battle of Hatfield Chase in 633, Bede describes how the Britons and the Mercians joined forces to terrorize the Northumbrians:

At this time there was a great slaughter both of the Church and of the people of Northumbria, one of the perpetrators being a heathen and the other a barbarian who was even more cruel than the heathen. Now Penda and the whole Mercian race were idolaters and ignorant of the name of Christ; but Cædwalla, although Christian by name and profession, was nevertheless a barbarian in heart and disposition and spared neither women nor innocent children. With bestial cruelty he put all to death by torture and for a long time raged through all their land, meaning to wipe out the whole English nation from the land of Britain. Nor did he pay any respect to the Christian religion which had sprung up amongst them. Indeed to this very day it is the habit of the Britons to despise the faith and religion of the English and not to co-operate with them in anything any more than with the heathen. ${ }^{74}$

Interestingly, Geoffrey does not shy away from this criticism of Cadwallon; indeed, he incorporates Bede's account almost verbatim. Cadwallon's persecution of the Northumbrians is described thus in the $D G B$ :

Merciorum finitimarumque prouinciarum, desecto capite perfido, ad fidei Chrisianae gratiam conuertit."

74 Bede, Ecclesiastical History ii.2o, ed. and trans. Colgrave and Mynors, pp. 202-05: "Quo tempore maxima est facta strages in ecclesia uel gente Nordanhymbrorum, maxime quod unus ex ducibus, a quibus acta est, paganus alter quia barbarus erat pagano saeuior. Siquidem Penda cum omni Merciorum gente idolis deditus et Christiani erat nominis ignarus; et uero Caedualla, quamuis nomen et professionem haberet Christiani, adeo tamen erat animo ac moribus barbarus, ut ne sexui quidem muliebri uel innocuae paruulorum parceret aetati, quin uniuersos atrocitate farina morti per tormenta contraderet, multo tempore totas eorum prouincias debachando peruagatus, ac totum genus Anglorum Brittaniae finibus erasurum se esse deliberans. Sed nec religioni Christianae, quae apud eos exorta erat, aliquid inpendebat honoris, quippe cum usque hodie moris sit Brettonum fidem religionemque Anglorum pro nihili habere, neque in aliquo eis magis communicare quam paganis." 
The victorious Cadwallon passed through all the provinces of the English, persecuting the Saxons so relentlessly that he spared neither women nor children; indeed he wanted to wipe out the whole English race from British soil, and subjected every one of them he could find to unheard-of tortures. ${ }^{75}$

While Geoffrey reproduces Bede's criticisms of Cadwallon's actions, Neil Wright has pointed out that he omits Bede's criticisms of Cadwallon himself: Cadwallon is not here described as animo ac moribus barbarus, "a barbarian in heart and disposition", for example. Furthermore, placed alongside the efforts of the Saxons to treacherously steal Britain from its rightful inhabitants, Cadwallon's actions do not appear unjustified. ${ }^{76}$ As discussed above, Bede's final statement of this passage, noting the continuing refusal of the Britons to cooperate with the Saxons, is in fact used by Geoffrey, but in a different section of the $D G B$, and in defense of the Britons. ${ }^{77}$ As an additional point it is interesting to note that, in the context of Geoffrey's work, Cadwallon's actions are not in fact that unusual. Indeed, prior to Cadwallon's victory, Edwin had inflicted a similar persecution on the lands of the Britons: "The victorious Edwinus led his army through the provinces of the Britons, burning cities and putting townand countrymen to the torture."78 Thus we see that Cadwallon is simply acting as Edwin acted before him. There is nothing particularly un-Christian about this (as is the implication in Bede's narrative); rather, it is simply the action of a victorious king.

A key part of Bede's criticism was that Cadwallon aligned himself with the pagan Mercians, when, as a Christian king, he should have known better. For Bede, as seen in the extract quoted above, Penda's actions are, if despicable, nonetheless understandable due to his ignorance of Christianity. However, Cadwallon's actions are inexcusable: he is a Christian, and yet acts like a barbarian, happier to cooperate with the pagan Mercians than with the Christian Northumbrians. Thus we are presented with a fairly clear-cut categorization

$75 \quad D G B$, xi.198.433-37: "Habita igitur uictoria, Caduallo uniuersas Anglorum prouincias peruagando ita debachatus est in Saxones ut ne sexui quidem muliebri uel paruulorum aetati parceret; quin omne genus Anglorum ex finibus Britanniae abradere uolens quoscumque reperiebat inauditis tormentis afficiebat." I have modernized the names to aid comparison with the other sources.

76 Wright, "Geoffrey of Monmouth and Bede", p. 42.

77 Wright, "Geoffrey of Monmouth and Bede", pp. 37-38. This is discussed further above, see p. 121 .

$78 \quad D G B$, xi.193.289-91: "At Edwinus, ut triumpho potitus fuit, duxit exercitum suum per prouincias Britonum combustisque ciuitatibus ciues et colonos pluribus tormentis affecit." 
of the Mercians and Britons in Bede's work: the former are pagans, the latter are Christians in name alone. This is picked up by Henry of Huntingdon, who explains that while Penda and the Mercians were pagans, "Cædwalla was more savage than a pagan." 79

Geoffrey's take on the matter is strikingly different. He does not seek to deny or diminish the holiness of the Northumbrian kings. As discussed above, he changes certain key details: for example, the battle of Heavenfield now occurs between Oswald and Penda, rather than Oswald and Cadwallon as in Bede. Despite this alteration in personnel, Geoffrey nonetheless repeats the episode of Oswald raising the cross of the Lord and beseeching his soldiers to kneel and pray to God for victory. However, crucially, Penda and the Mercians are never described as pagans in Geoffrey's narrative. Penda is simply rex Merciorum, "king of the Mercians", and while he is referred to as a nefandi ducis, "wicked leader", his paganism is never mentioned..$^{80}$ As a consequence, there are no questions raised over Cadwallon's alliance with Penda. It is simply an alliance between two kings; in Geoffrey's narrative there remains no trace of Bede's presentation of the unnatural alliance between a supposed Christian and a heathen people. This is a subtle shift in perception, but it has a significant impact on the overall tone of the narrative. Cadwallon's actions are viewed in a completely different light, not because the actions themselves have necessarily changed (at least in the case of his alliance with Penda and killing of Edwin), but because these actions are depicted in a subtly different way. Geoffrey's Cadwallon, then, is not the bad Christian portrayed by Bede.

This is not to say that there are no bad Christian kings in Geoffrey's narrative. Bede views Cadwallon as fulfilling this role due to his alliance with the heathen Mercians and attacks on the pious Northumbrians, yet Geoffrey in fact has someone else in mind: Æthelberht of Kent (d. 616?). Here we must return to the meeting between Augustine and the Britons discussed above. In Bede's account, there are seven British bishops and many learned men at the meeting, mainly from the monastery of Bangor Iscoed, under the authority of Abbot Dinoot. When they refuse Augustine's requests, he warns them that refusal to preach to the Saxons will result in death at their hands. Bede immediately relates how this came to pass, as Æthelfrith, king of the Northumbrians, brought an army to Chester to battle against the Britons. When he saw that the priests (most from the monastery of Bangor) had assembled to pray for a

79 Henry of Huntingdon, History of the English iii.33, ed. and trans. Greenway, pp. 184-85: “... Cedwalla uero pagano seuior."

8o There are several references to Penda as rex Merciorum: $D G B$, xi.196.417; xi.199.443; xi.200.462. For nefandi ducis, see xi.199.443. 
Northumbrian defeat, he ordered that they be slaughtered first. Their guard, Brocmail, fled, and about 1,200 of the priests were killed. ${ }^{81}$

This episode is once more heavily altered by Geoffrey in a way that reflects more positively upon the Britons. Rather than praying for the defeat of the English, in Geoffrey's account the monks are praying for the safety of their own people, and rather than flee, Brocmail dies trying to protect the city. ${ }^{82}$ The monks, who in Geoffrey's account are slaughtered after the battle, are presented as martyrs. ${ }^{83}$ What is significant in the present context is the reason given for Æthelfrith's attack. Bede does not tell us what prompted Æthelfrith to march on Chester, he simply presents it as a fulfilment of Augustine's prophecy. Geoffrey, however, states the following:

Æthelberht, king of Kent, indignant that the Britons had refused to submit to Augustine and had rejected his preaching, incited Æthelfrith, king of Northumbria, and the other Saxon subkings to collect a great army and go to the city of Bangor to kill Dinoot and the other priests who had slighted them. ${ }^{84}$

This is a dramatic departure from Bede's account, and, as Wright notes, "Ethelfrid is represented as the cats-paw of Ethelbert of Kent (and hence indirectly of Augustine himself)." 85 The reframing of this episode has a significant impact on the above discussion of how Geoffrey neutralizes Bede's complaint against the Britons. Bede attacks Cadwallon for supporting a pagan king against a Christian people. Here, Æthelberht of Kent, a Christian king (indeed, the first Christian king according to Bede's narrative), facilitates the killing of the priests of Bangor and their abbot Dinoot. It is not, as in Bede's account, an attack on the Britons that simply happens to end in the slaughter of the priests, but rather a targeted attack against the priests themselves. Nor is it simply the work of a pagan king as in Bede's narrative: here it is a Christian king who gives the order. This has the effect of turning Bede's characterization on its head.

\footnotetext{
81 Bede, Ecclesiastical History ii.2, ed. and trans. Colgrave and Mynors, pp. 136-41.

$82 \quad D G B, \mathrm{xi}, 189.206-8$.

83 Wright, "Geoffrey of Monmouth and Bede", pp. 39-40.

84 DGB, xi.189.195-200: "Edelbertus ergo rex Cantiorum, ut uidit Britones dedignantes subiectionem Augustino facere et eosdem praedicationem suam spernere, hoc grauissime ferens Edelfridum regem Northamhimbrorum et ceteros regulos Saxonum instimulauit ut collecto grandi exercitu in ciuitatem Bangor abbatem Dinoot et ceteros clericos qui eos despexerant perditum irent."

85 Wright, "Geoffrey of Monmouth and Bede", p. 39.
} 
It is perhaps significant that this re-casting of the Britons, Northumbrians, and Mercians is thematically consistent with the treatment accorded to the Saxons in the section of the $D G B$ concerning the adventus Saxonum, discussed above. In both cases, faith is a defining characteristic which Geoffrey grapples with, whether to stress the paganism of the Saxons or to neutralize Bede's depiction of the Britons as bad Christians. While it is generally recognized that Geoffrey's $D G B$ represents a shift away from the providential toward a more secular and national history, with a focus on individuals and the role of fortune, it is clear from this discussion that ideas of conversion and faith remain important to his narrative. ${ }^{86}$ Such ideas are prevalent in his source material, especially the Ecclesiastical History, and this discussion has illustrated how Geoffrey went beyond simply subverting Bede's chronology in his engagement with this text. To the modern reader, the obvious, bold changes made to Bede's narrative, such as the extension of Cadwallon's life, perhaps deflect attention from the more subtle changes, such as the depiction of Æthelberht of Kent as a villain. The consequence of this adaptation of, and divergence from, the Ecclesiastical History is an account of 6th- and 7th-century relations between the Britons and English which is unprecedented in its positive treatment of the former.

\section{Conclusions}

For Geoffrey, the English only begin to achieve dominance over Britain after the death of Cadwaladr in 689, a trajectory completed by Æthelstan becoming the first Saxon king to rule all Loegria in the 1oth century. Prior to this, the past was British, and the English only relevant inasmuch as they interacted with the Britons. They may have experienced brief moments of supremacy, but these were never more than moments. Edwin enjoyed a spell of overlordship having expelled Cadwallon from Britain, but Cadwallon returned, and Edwin's overlordship died with him. The domination of the English was never lasting, and the Britons were never permanently subdued. Indeed, in the end, it was not the military might of the English that defeated the Britons, but a plague with the force of God's will.

In creating this original and creative version of history, Geoffrey struck his own path, leaving his sources behind. Consequently, the $D G B$ is full of plot twists to shock any reader familiar with the conventional narrative of

86 Hanning, Vision of History, pp. 138-39. For further discussion, see Barry Lewis's chapter in this volume. 
English history: individuals do not live and die at the expected time, and battles are fought at unexpected places and with surprising casts. But despite his efforts to create something new, Geoffrey remained conscious of what had come before. Indeed, for his account of the adventus Saxonum we have seen that he follows Historia Brittonum's lead, with his additions, while undoubtedly creative, simply accentuating themes already present in the 9th-century history of the Britons. His approach to the Ecclesiastical History is clearly different: Geoffrey has no problem in turning Bede's narrative on its head to suit his own purposes. However, even here we see a keen awareness of prior tradition. In producing his alternative narrative, Geoffrey does not simply ignore Bede; he takes and carefully alters episodes from the Ecclesiastical History, adding detail, emphasis, and different context to change the fundamental message of the work.

The past was not viewed as uncharted territory in the 12th century, and it is in this context that we should understand Geoffrey's careful treatment of his sources. ${ }^{87}$ Monika Otter has illustrated how Geoffrey plays with the principle of textual auctoritas: through alleging reliance on the liber uetustissimus, "very ancient book", Geoffrey provides the appearance of textual authority for the $D G B$, making the same claim to truth as other 12th-century histories, while simultaneously ensuring that his account is unverifiable. ${ }^{88}$ This discussion has illustrated that his treatment of known sources is equally complex. That Geoffrey diverges from the received chronology of early medieval British history has long been recognized, but there are also further layers to his engagement with sources such as Bede's Ecclesiastical History. Interestingly, in the instances considered here, every addition Geoffrey makes to his sources, every event he decides to exclude, or include in a different form, works to present the Britons in a favorable light. Geoffrey's attitude toward the English past cannot be understood independently of this context. This is not to say that he sets out to consistently depict the Britons as the heroes of his history; the influence of Gildas's criticisms of his countrymen can be felt in the focus on civil war in the $D G B$, for example. Neither can this sympathy for the Britons be neatly mapped on to a 12th-century landscape; indeed, Geoffrey stresses the disconnect between the Britons of the $D G B$ and the Welsh of his own time. However, the $D G B$ 's account of the adventus Saxonum and 6th- and 7th-century relations between the Britons and the English reflects better on the Britons than the work of any writer that preceded Geoffrey. In this context, early medieval England belonged to the Britons.

87 Otter, Inventiones, p. 83 .

88 Otter, "Functions of Fiction", p. 120. 